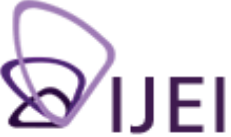

International Journal for

Educational Integrity

\section{"I can't say it any better": Critical reading as a threshold concept in helping postgraduate Arab students become critical and original writers}

\author{
Radhika lyer-O'Sullivan \\ radhikaiyeros@gmail.com
}

Keywords: academic integrity, critical writing skills, reading, threshold concepts

A previous version of this paper was presented at the 5th International Integrity and Plagiarism Conference, Newcastle-Upon-Tyne, UK, 16-18 July 2012.

\begin{abstract}
Many studies on plagiarism issues across the globe have arrived at the consensus that in dealing with plagiarism, universities need to do more than provide students with policies and procedures. Education, via academic support classes, has been touted as the way forward in teaching students to develop academic writing skills and avoid plagiarism. Teaching postgraduate students to produce academic writing that is analytical while retaining their individual expression has been a challenge at the British University in Dubai (BUiD). Most of the students at the university come from mainly Arab educational backgrounds. This could mean that their education may not have been in English but more importantly, that they may also have been entrenched in different learning and teaching styles. Previously encouraged to rely on restating exactly what they have read may contribute to students' inability to express critical thought through their writing. Based on analysis of students' critical writing through faculty feedback, samples of student writing and Turnitin reports, this paper seeks to demonstrate that teaching critical reading skills as a threshold concept that translates into critical thinking skills will help students adopt a different approach to reading, which will subsequently help develop critical writing skills. This paper will show how pedagogy was developed to enable students to read critically and produce coherent and thoughtful critical writing while retaining academic integrity.
\end{abstract}

\section{Introduction}

In the last decade, the trend in many universities has been to set up learner support or academic support units because it was perceived that students entering higher education were not necessarily equipped with the academic literacy and study skills required to cope with higher education (Magyar, 2012). In addition, with the onset of the internet and students' dependence on online resources, plagiarism has become the buzz factor among academic circles and the onus has fallen on study skills units to take preventative measures.

Initially, many universities were content to give students an academic guide or handbook that contained tips on academic writing and some explanation on university policy about plagiarism detection and prevention. Later, it was found that giving students explicit documentation alone was not sufficient. Students either do not read the policies or fail to understand the practical implications of the policies (Macdonald \& Carroll, 2006). As a result, most universities have formed special support units which deliver workshops and classes on various academic literacy skills (McGowan,

The International Journal for Educational Integrity is available online at:

http://www.ojs.unisa.edu.au/journals/index.php/IJEl/

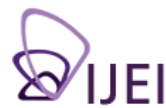


2005). This measure was taken by universities not only to educate and prepare students for higher education but also to protect themselves. When a student is failed due to reasons pertaining to plagiarism or poor writing skills, the student can rightfully argue that he/she was not taught how to write, given sustained, formative feedback on how to improve his/her writing or received relevant academic skills. This has triggered institutions to develop curriculum in teaching of academic writing (Johnson \& Clerehan, 2005). By offering academic support classes, universities can then compel students to take responsibility and use the support available (Walker, 1998). In universities which boast large groups of international students, it has been a worthwhile exercise to make these classes part of a non-credit bearing but mandatory pre-degree module.

\section{The scramble to teach academic writing}

In light of the above issues, what many universities or institutions of higher education have done is offer generic academic writing classes that have focused on teaching writing through the use of genres such as descriptions, arguments, giving solutions and report writing. Genre-analysis was seen as the effective tool for reducing inadvertent plagiarism and as a platform for "using reading to inform writing" (McGowan, 2005, p. 52). While this focus on genre may be helpful and useful for undergraduate students to a certain extent, it has been found not as equally beneficial at postgraduate level. This paper will explore how genre-focused academic reading and writing classes have not been completely successful in enabling graduate students to cope with writing at the graduate level. Many students' papers tend to remain in the form of heavily descriptive summaries or their attempts to be critical may actually be copied critical chunks from texts.

This study will particularly focus on the masters students at the British University in Dubai (BUiD). The BUiD is a young research-based institution in Dubai, United Arab Emirates, that currently offers postgraduate programmes across subjects. Currently, it has just over 500 registered students. It is generally assumed that students who enroll for masters or doctoral programmes have the prerequisite language and literacy skills required to produce research-oriented, intuitive and comprehensive work at graduate level; however, it has also been found that graduate students too need support in those aspects (Davies, 2011). This is due to a plethora of factors. Some graduate students may have pursued their bachelor's degree and school system in a completely examination-oriented context and not actually had the opportunity to write an assignment. In such cases, expecting students to produce a 5,000-word research paper can sometimes result in the student, the programme and the tutors facing an indomitable barrier. Students may have the language proficiency and academic knowhow to produce such a paper; looking at samples or following the structure of journal articles may also eventually contribute to them producing an acceptable piece of work. Nevertheless, what has been found at BUiD is that many students lack the critical writing skills that can contribute to a paper being analytical. Faculties across programmes felt that while students' work demonstrated evidence of a wide range of readings, significant research undertaken and analysis of data, it lacked critical analysis in linking the findings to existing literature in the area of study. Because the majority of BUiD students are of Arab origin, many faculties felt that Arab students do not know how to or are incapable of demonstrating critical thought in academic contexts.

Thus, this study explores the content of academic support classes delivered to postgraduate students at BUiD between January and December 2011, and shows how teaching language-focused academic literacy skills was insufficient to develop students' critical writing skills. It also outlines how development of pedagogy based on teaching critical reading skills as a threshold concept can help students enhance analytical and critical writing skills. This study was conducted on the hypothesis that teaching 'traditional' genre- and language-based writing skills may inhibit students' 
critical writing skills and that teaching students to take a different approach to their readings may help them think critically and translate those critical thoughts into their writing. The objectives embedded within this aim were:

- $\quad$ development of pedagogy that begins with a basis of critical reading as a threshold concept;

- $\quad$ to demonstrate that such a pedagogy will contribute to students developing writing skills that are critical and analytical; and

- $\quad$ to show that Arab students are capable of critical thought but may need some support in expressing critical thought in academic writing contexts.

The study specifically focused on Masters of Education (M.Ed) students as this is the largest cohort in the university and the education students engage with academic support most frequently. The study began in September 2010 and presents data collected until December 2011, although it is expected that this project will continue into the future.

\section{Literature review: From writing to reading}

Critical thinking has been a hotly debated concept for a long time within the realm of education. In any global education context that is involved in educational reform, the concept of critical thinking usually becomes a pertinent issue. Education systems worldwide are constantly concerned that they are churning out students who cannot think critically (Ozmen, 2008). A similar concern has been increasingly expressed among faculties across programmes at the BUiD. At postgraduate levels, demonstration of critical expression, and argument in writing are seen as evidence of a student's ability to think critically (Johns, 1997).

This section will initially discuss the importance of teaching academic literacy and study skills explicitly to postgraduate students and then show how focusing on teaching writing or genre writing may actually be insufficient for students' development of critical writing skills while sustaining originality. Following this, the next section explores how teaching critical reading skills as a threshold concept can help develop students' critical writing skills and original ideas.

\section{The genre-analysis bandwagon}

As universities began to realise the importance of transparency in dealing with plagiarism issues, many institutions clambered to develop student handbooks that contained vast amounts of information on the rules, regulations and penalties associated with plagiarism. However, it soon became evident that just giving information to students is insufficient (McGowan, 2005). Research into use of 'negative language' in student handbooks and students' low confidence led to the realisation that some active learning and teaching needed to take place for students to be able to grasp and apply original ideas. Many EAP (English for Academic Purposes) teachers have lauded the concept of using reading as a basis for informing writing. Unfortunately, this concept has given way to focusing on genres and developing genre writing. While this may have been useful for undergraduate students in writing an essay (Umair, 2011), it has become problematic for non-native speakers of English at postgraduate level who are expected to produce research papers that demand an array of genres to be used simultaneously.

At postgraduate level, students have to produce research-based assignments that most often also require critical reviews of literature and demonstration of original thought in discussions. In accordance with this, Johnson and Clerehan (2005) claim that 'criticality' and 'originality' began to be seen as desired features of assignments. Thus, it is not enough just to regurgitate others' opinions but students need to form 
their own opinions based on "research and reasoning" (p. 43). They further argue that this can be problematic for students as, while sometimes they can present 'original' ideas, these may be deemed unreliable as they did not build these ideas based on others' theories, and the students will also be confused in differentiating their own opinions from others. Chanock (2002, p. 3) substantiates this further by her rebuke against dolling out plagiarism advice as students "may be experts on their own opinion but they are novices in the context within which it is being sought". This is when students, because of reluctance to challenge what they read, may end up regurgitating what they have read. They can perhaps see that the author is already being critical but are unable to impose their own layer of criticism as they have limited themselves within their status as students and the author's status as expert. Chanock also strongly feels that academics are ruled by the convention that students should always be critical. This can be daunting even for a postgraduate who is considered as a near-native speaker because it does not only demand linguistic competence but expression of critical opinion within the boundaries of academic rhetoric.

Badley (2009) gives fresh insight to how particular terms used by higher education institutions can create those boundaries that suppress students' critical writing abilities. Some institutions use the term 'writing-up' in their study guides, assignment guidelines and handbooks. Badley contends that the very notion of 'writing-up' can render writing an assignment as an uncreative process as it seems to suggest that the writing process is passive. For Badley, good academic writing is a "problematic and tentative exercise in critical reflective thinking" (p. 209), and the best way to engage in this exercise is to "deconstruct and reconstruct" texts (p. 212). The implications of approaches to reading upon using these features will be discussed later in the paper.

\section{The critical thinking mantra}

Many Western-educated academics pride themselves as critical thinkers and thus tend to easily dismiss students' inability to express critical thought as students not being capable of critical thought. While globally curriculum is constantly challenged and evolving, what has prevailed is the emphasis on producing a generation that is able to think well and critically. The notion that a Western model of education allows more opportunities for developing critical thinking has been widely accepted (Xie, 2012). This is contrasted with education systems in developing countries that are usually criticised for adapting rote-learning and memorisation techniques which are seen to debilitate a student's thinking abilities. Within this context, the Emirates Centre for Strategies Studies and Research (ECCSR, 2004, p. 1) reports that Arab educational systems have also been under scrutiny and critics have described them as "obsolete, consistently failing generations of Arab students and squandering [students'] creativity and productive capabilities". However, the only evidence to support this comes from rankings of Arab countries in the Trends in Mathematical and Science Study (TIMSS). The connection between low rankings in mathematics and science and poor critical thinking is not properly clarified and appears to be tenuous. Bolitho (2012) believes that the concept of critical thinking tends to bubble to the surface as a cross-curricular objective every few years but it is an objective that is "everybody's aim but is nobody's business". He asserts that even the elementary learner is capable of critical thought; it is the lack of linguistic tools, perhaps further diminished in foreign language contexts, that inhibits expression of critical thought.

Al-Hazmi (2006) describes the EFL (English as a Foreign Language) teaching of writing context in the Arab regions as "abstracted, depersonalized and productoriented" (p. 36). His recommendation is that writing should be taught as a process to promote self-reflection and critical thinking. The results of his study, which were based on student perceptions of learning to write amidst an altered pedagogy, presented an interesting angle. In the questionnaire responses to Al-Hazmi's survey, many students responded that they enjoyed the classes more because of the interesting discussions on writing. While it is quite evident that Arab students are able to 'talk' critically when 
reflecting on their own or others' writing, the same analytical behaviour appears to diminish in the finished product of writing.

The same issue was found within the context of the present study. All academics at BUiD claimed that in group discussions, students were highly critical, argumentative and analytical; but when it came to writing, these features were hardly noticeable. Al Yahya (2011) claims that Arab students do not differ much from students in the US in their ability to think critically, make choices or question assumptions in talks and discussions but this ability sometimes does not surface in their writing. In addressing this paradox, Daniel (2003, p. 1) laments how the rich educational tradition of the Arab world in the past has slowly eroded over time: "The great weaknesses of the Arab world are the lack of freedom, the lack of knowledge...compare this to the intellectual effervescence of this region a thousand years ago, an effervescence which drove the development of knowledge in a wide range of practical and more theoretical areas". Thus, it is evident that Arab students have a tradition of enquiry and critical thought in education but some underlying factors appear to curtail their ability to write critically.

\section{Critical reading as a threshold concept}

Academic reading and critical reading are 'taken-for-granted' skills that most institutions assume students already possess. Even if these skills are offered as part of a package in academic support classes, they may feature at the beginning of the course, amounting to about two to four hours of total teaching time. Subsequently, most courses tend to quickly move on to writing skills. Within the area of genre writing especially, writing can be divided into various categories and offered as separate classes. This tends to give the impression to students that reading is not an important part, let alone integral to their development as an academic writer. By mainly focusing on writing skills, a postgraduate student may learn the accurate grammatical tools such as discourse markers, academic phrasing and referencing but more importantly, they will also inadvertently learn that their reading merely feeds into their writing (Harwood \& Hadley, 2004). Thus, the entire concept of reading critically is shelved as students focus on the finished product of writing.

The approach of absorbing and regurgitating content of readings could be exacerbated by students' previous educational backgrounds. Some Arab universities still have examination-oriented systems where students attend lectures, study and sit for examinations to graduate. Many students are not required to write an assignment at undergraduate level. In primary and secondary schools too, students have been taught to copy chunks of text into their copy books without any apparent learning objective. A 1995 study that investigated the quality of schooling in the Arab region showed that students were trained to "memorise and retain answers to 'fairly fixed questions' with little or no meaningful context" (Whitaker, 2009, p. 1). A World Bank report done 13 years later reinforced that little has changed in terms of educational reform and that students are mainly still 'passive knowledge recipients'. If this is true then it is possible that Arab students have habitually received knowledge through readings and this passive approach to reading is something that they are likely bring to higher education as well.

\section{Methodological approach}

As mentioned earlier, the approach applied in this study was to redesign pedagogy, embed critical reading activities in two selected writing workshops and then evaluate the impact of these activities on students' critical writing skills. Thus, it was decided to conduct a small pilot case study with a selected group of students from one programme who would be registered in modules that had similar assessment tasks. In exploring the meaning of a case study, Hancock and Algozzine (2006) have further built on Yin's (2003) definition to explain that case study research "means conducting 
an empirical investigation of a contemporary phenomenon within its natural context using multiple sources of evidence" (p. 15). Although, in this case study, the sources of evidence are rather limited, it is still an opportunity to conduct an exploratory study to establish feasibility of the selected approaches.

As most of the students who regularly attend study skills workshops tend to be M.Ed students, the sample group comprised ten M.Ed students in their second semester of study. Seven out of these ten students had also been identified as 'at-risk' students who had been exhibiting poor academic writing skills. Anecdotal feedback from faculty members showed that while many students had language fluency and proficiency, they were not good academic writers because they were not sufficiently critical. Critical writing was equated with critical thinking and the decision was made to offer critical thinking workshops in the following semester. This critical thinking workshop mainly included activities, exercises and games that were designed to develop students' critical and analytical thinking. Reading was part of the content but only as a supplementary activity.

In addition to the above seven identified students, another three students who were seen as 'stronger writers' were also included in the case study sample. This was because with extra support in the form of attendance at workshops and individual support via the Writing Centre, it was possible that students may show improvement even if workshop content remained unchanged. Thus, it was also equally viable to see if the students identified as stronger writers also improved with the suggested new pedagogy.

In this case study, the ten M.Ed students consisted of six men and four women, aged between 30 to 40 years. They were all ethnically Arab and had all obtained an undergraduate degree from an institution based in an Arab country. The initial data collection involved selecting and examining Turnitin reports of these ten students. The same assignment was selected to avoid ambiguity in terms of task interpretation and task fulfillment. The assignment selected was a critical review done for a core Research Methods module. Although some of the students had passed the assignment, the feedback comments from the marker indicated that students needed to be more critical.

However, further feedback from academics and work brought to the Writing Centre following these additional critical thinking workshops indicated that while some improvement was evident in students' academic phrasing, their work still lacked critical argument. In light of this, it became clear that isolated activities on critical thinking were not fulfilling the outcome of helping students to write critically. This has been proven in other studies too, which assert that critical thinking skills should be embedded within all subject areas and not taught in isolation (Pithers \& Soden, 2000; Lloyd \& Bahr, 2010).

Data collection to determine the levels of students' critical writing comprised two modes. The first was to analyse samples of student writing and look at some of the feedback comments from markers, and the second was to analyse the Turnitin reports of the same assignments to determine how students had used sources. As the university had begun piloting submission of assignments through Turnitin in January 2011, it became evident that Turnitin reports could be used as a tool for evaluating students' critical writing levels too. Based on the first two stages, pedagogy that positioned critical reading skills as a threshold concept was adopted and then students' writing was analysed at the Writing Centre.

\section{Redesigning pedagogy}

To begin analysing student writing, the first step was to look at marker feedback. The feedback for all seven papers mainly focused on students' weaknesses in expressing 
critical opinion and argument. The next step was to examine the Turnitin reports of the seven students to identify use of sources and evidence of criticality. Although Turnitin is widely used in many institutions to help identify plagiarism, it can also be an extremely useful tool to evaluate writing. As Turnitin highlights exact words from sources as coloured 'chunks', it was interesting to focus on the highlighted text and look for the amount and quality of black text either before or after the coloured chunks. As citations were also highlighted, it was easy to locate citations and scrutinise accompanying text in order to determine critical discourse. For the purpose of confidentiality, the actual Turnitin reports could not be attached here.

The findings showed that there were some common, identifiable problems among all seven assignments. Students had mainly patched together a series of quotes with little critical comment or analysis. However, there are glimpses of student voice that do show potential of the student within the instances of 'patchwriting' which Howard (cited in Pecorari, 2003) describes as what students do when they have either not understood what they have read or are unable to exercise the discourse required to discuss the reading. Much of the writing too was in the form of descriptive summaries of works read. This was confirmed by student attitudes to reading, which were revealed in workshops through refrains such as "I can't say it any better" and "how can we criticise experts?".

Based on this initial analysis and sources of evidence, the decision was made to redesign the pedagogy of some of the writing workshop content to include critical reading skills. To restore the importance of reading and reading approaches, it was decided that critical reading needed to be taught explicitly. This meant not just offering a one-off workshop on academic reading or critical thinking, but that critical reading strategies needed to be integrated, taught and reinforced explicitly in all writing workshops.

To be able to write critically, students should change the way they read. This can be considered to be a threshold concept as it represents a "transformed way of understanding, or interpreting or viewing something, without which the learner cannot progress" (Meyer \& Land, 2003). While work on threshold concepts has largely been within higher education, much of it has been in the area of business, economic and technology. Although a study was conducted in China (Xie, 2012) which applied the 'Reading-Discussion-Writing' approach to cultivate critical thinking among Chinese undergraduate students, the idea of threshold concepts within teaching academic literacy skills to postgraduate students remains uncharted. However, there have been extensive ideas generated about the effectiveness of threshold concepts in relation to learning. Carey's $(1991,2000)$ work aligns threshold concepts to cognitive change and 'transformative learning'. In the same light, Entwhistle, McCune and Hounsell (2002) recommend that teaching methodologies need to be reviewed, and Cousin (2006) asserts that a change in learner identity is desirable. Thus, redesigning pedagogy and applying critical reading as a threshold concept was seen to be appropriate and timely. According to Atherton (2011), threshold concepts are not just about core or central ideas of a subject. It could very well be something that is obvious and has been inadvertently neglected but when resurrected could radically change the way students think about a subject. In teaching critical reading skills as a threshold concept, the emphasis is on showing students how to actively engage with the text by questioning and debating through disciplined and controlled processes. At initial stages, some models of questioning strategies can also be given as they can "provide students with a window into the thinking an expert uses when questioning" (Wilson \& Smetana, 2011, p. 88).

Figure 1 illustrates the process of how critical reading as a threshold concept flows into development of writing using some aspects of critical thinking skills (Cottrell, 2001, 2005), critical reading techniques (Memering \& Palmer, 2002) and guidelines on developing critical writing skills (Hart, 1998). 


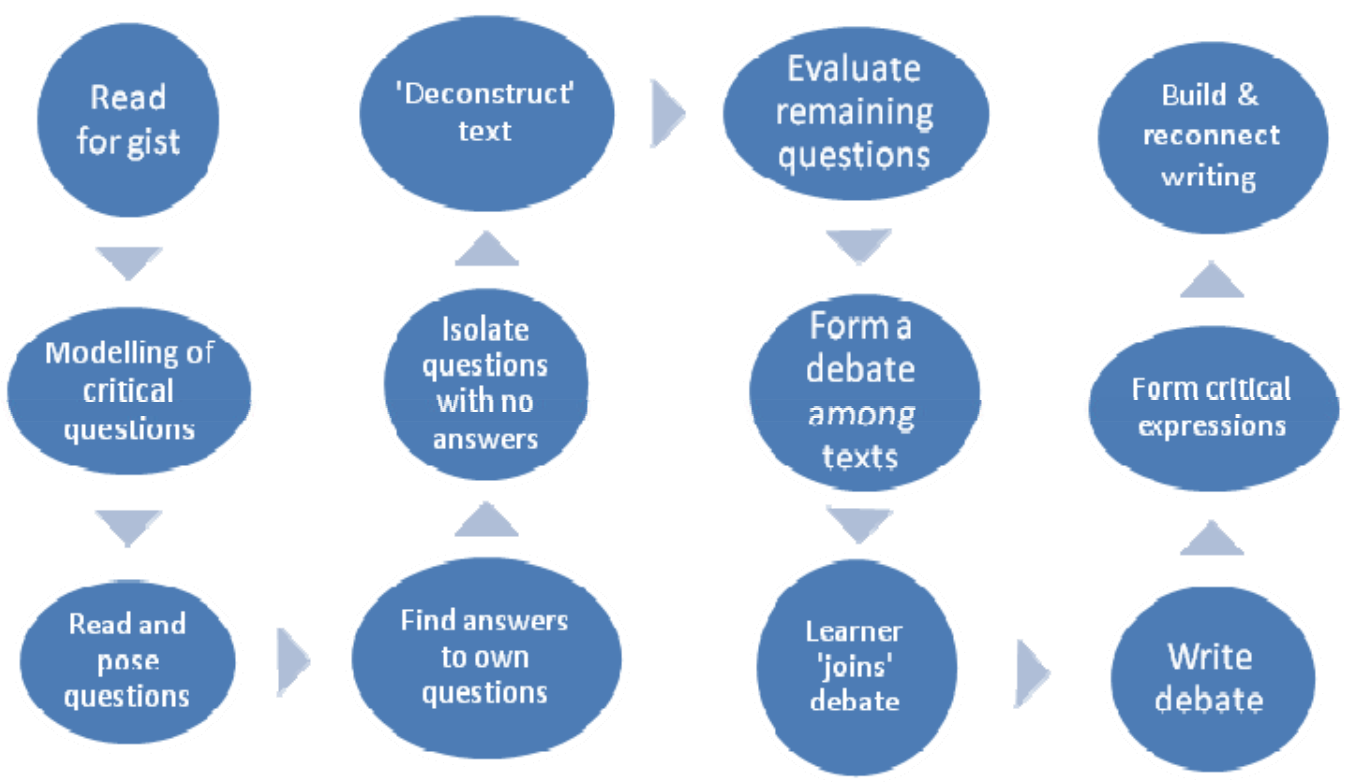

Figure 1: Explicit reading strategies towards writing critically

As discussed earlier, studies that advocate explicit teaching of academic writing are aware of the importance of starting with reading and using texts as a base for students to develop writing skills. However, using texts in EAP classes have been predominantly to identify particular linguistic devices or for genre-analysis. The genre approach is valid in terms of dynamism that can vary "across time, across disciplines and across instructors in the disciplines" (Khasawneh, 2010, p. 9); however, it is restricted to helping students learn the conventions of a particular form relevant to limited situations. In bringing back reading as a threshold concept, texts also need to be 'deconstructed'. Badley (2009) emphasises that this does not mean finding deliberate fault with the text but recommends building on Derrida's (1994) suggestion of examining texts deeply. By doing the latter, Badley reiterates that "deconstruction creates tension between a conservative fidelity to existing texts and the radical possibility of something new, some new insight or interpretation..." (p. 212). He strongly contends that only by collecting, analysing, evaluating and interpreting educational texts can students then 'reconstruct' (write) by re-collecting, re-evaluating, re-interpreting and finally, synthesising.

\section{Impact on students}

The focus of this study was to evaluate new pedagogy. One source of evidence in this case study included obtaining students' comments on new workshop content. During appointments at the Writing Centre, students were asked what they felt about the critical reading components of the workshops and how, if at all, they had contributed to their writing. The seven students made the following comments:

Student 1 - "I just used to read and regurgitate, I didn't think about what I read." Student 2 - "For me, it was important only to understand all vocabulary and general content of text, only now I know how to question what I read."

Student 3 - "I always only saw the writers as experts, now I know I am expert too in different ways."

Student 4 - "I had some opinions but I thought they were not 'academic' enough, that's why I only used opinions of others in my work."

Student 5 - "I thought my opinion should only be to the point what I agree and disagree with. Only now I have learnt to support my agreements and disagreements with opinions of others and then re-evaluate those opinions." 
Student 6 - "I liked idea of pretending that the authors were in the room and we could engage in a debate with them. This helped me to form arguments using my own words."

Student 7 - "I liked interacting with the text rather than absorbing content like a sponge."

While students' responses seem to indicate that some transformation had occurred in the way they approached their reading and noticeable improvement was perceived in students' drafts, it was also useful to see if students' grades had improved for their next assignment. The second assignment was similar to the first as it was also a critique; while the first one was a critique of an article, the second was a critique of a selected educational policy.

Table 1 shows the grades students attained in the first and second assignment. In terms of these results, the grades are viewed as evidence of improvement in critical writing and the Turnitin percentage is seen as evidence of originality. Of course using Turnitin similarity indexes as indicators of improved writing quality can be rather dubious; however, they were not used to determine changed levels of plagiarism. The similarity reports helped reveal salient aspects of student writing. While this study mainly drew conclusions based on students' work and their own shared verbal reflections (see below), the Turnitin text match percentages gave interesting data on individual student's understanding of citation and attribution.

\begin{tabular}{|c|c|c|c|c|}
\hline $\begin{array}{c}\text { M.Ed } \\
\text { Students }\end{array}$ & $\begin{array}{c}\text { Module } \\
\text { Grade } \\
\text { Semester 1 }\end{array}$ & $\begin{array}{c}\text { Turnitin } \\
\text { similarity } \\
\text { index } \\
\text { (Semester 1) }\end{array}$ & $\begin{array}{c}\text { Module Grade } \\
\text { Semester 2 } \\
\text { (post-new } \\
\text { pedagogy) }\end{array}$ & $\begin{array}{c}\text { Turnitin } \\
\text { Similarity } \\
\text { Index } \\
\text { (Semester 2) }\end{array}$ \\
\hline Student 1 & $\mathrm{D}$ & $32 \%$ & $\mathrm{C}$ & $21 \%$ \\
\hline Student 2 & $\mathrm{D}$ & $26 \%$ & $\mathrm{C}$ & $22 \%$ \\
\hline Student 3 & $\mathrm{C}$ & $24 \%$ & $\mathrm{~B}$ & $25 \%$ \\
\hline Student 4 & $\mathrm{C}$ & $8 \%$ & $\mathrm{~B}$ & $9 \%$ \\
\hline Student 5 & $\mathrm{C}$ & $28 \%$ & $\mathrm{C}$ & $12 \%$ \\
\hline Student 6 & $\mathrm{C}$ & $32 \%$ & $\mathrm{~A}$ & $5 \%$ \\
\hline Student 7 & $\mathrm{D}$ & $26 \%$ & $\mathrm{D}$ & $28 \%$ \\
\hline Student 8 & $\mathrm{B}$ & $15 \%$ & $\mathrm{~A}$ & $5 \%$ \\
\hline Student 9 & $\mathrm{B}$ & $12 \%$ & $\mathrm{~B}$ & $9 \%$ \\
\hline Student 10 & $\mathrm{B}$ & $16 \%$ & $\mathrm{~A}$ & $9 \%$ \\
\hline
\end{tabular}

Table 1:

Assignment grades of case study group

The results reveal that students' grades generally did improve and that students who had failed the first critique assignment, managed to pass in Semester 2. Only one of the failing students failed again and still had issues with originality. Two other students' grades remained the same but the Turnitin index decreased. It is interesting to note that the three additional students (who were considered to be strong writers) 
chosen to be included in the study also showed some improvement in either grades, similarity index percentages or both. As clarified earlier, the Turnitin similarity index was used to investigate students' usage of sources, extent of use and levels of critical writing. One issue with this study is that because the case study was built on initial students' grades and marker comments, it became necessary to obtain Semester 2 Turnitin reports to make a comparison. However, only information regarding the percentages of the reports were obtained and thus, access to the full Turnitin reports was limited. This meant that preliminary conclusions regarding impact of the new pedagogy on students' writing were mainly drawn from student opinions, students' drafts at the Writing Centre and grades.

Admittedly, other factors could have contributed to students getting higher grades such as looking at a peer's assignments or engaging in independent learning involving writing tasks to improve their own writing but during individual appointments, most of these students admitted that they had only briefly engaged in self-learning through recommended online resources. No data was collected in the form of formal questionnaires nor interviews done to gauge student perceptions on how change in pedagogy had affected their learning and writing. This was deliberate because the idea was for students to assimilate the threshold concept without being too conscious that they were learning academic writing in a different way.

\section{Conclusion}

Based on the limited evidence in this small case study of ten M.Ed students, it is difficult to generalise that critical reading as a threshold concept can enhance critical writing skills among postgraduate students. Nevertheless, early evidence that teaching critical reading strategies as a threshold concept and departing from genre analysis does indicate that these strategies can help students alter their attitudes to reading, develop a more critical approach to texts and then translate these thoughts into their academic writing.

Although many teachers' practices of teaching academic writing may resonate with the above, it would be difficult to initiate curricular and pedagogical change, especially in larger institutions, where students expect to be taught writing in an academic writing class, not reading. Some studies have attempted to address this issue. By using the metaphor of 'bootstrapping', Carey (2004) explains that in returning to core concepts, innate beliefs of students have to be initially identified, followed by understanding how the target concept is different from the innate representation and then define the "learning mechanisms" (p. 60) that would enable the core concept to be rebuilt. Thus, the practice of idealising texts leading to weak writing and sometimes plagiarism, may have become innate for many Arab learners. These students need to be taught to resurrect some of their dormant reading skills, learn and assimilate new critical reading skills, and learn how to "interrogate" (Johnson \& Clerehan, 2005) academic texts to avoid naive criticism. Then they need to socialise themselves into the academic context required and subsequently reconstruct their thoughts into writing. Ultimately, the successful implementation of critical reading skills as a threshold concept in enhancing critical writing and originality should awaken in students the realisation that they do not need to 'say it better' than the text; rather they need to analyse what has been said and 'say it differently' with supporting evidence. For this study, curricular content was redesigned on the basis of anecdotal evidence that comprised students' feedback during classes, marker comments and the researcher's own reflective practice. The next step is to formally position this study within a defined mixed methods research approach to map curricular and pedagogical change, gauge academics' and student perceptions, and align those with module grades and originality reports. 


\section{References}

Al-Hazmi, S. (2006). Writing and reflection: Perceptions of Arab EFL learners. South Asian Language Review, XVI(2), 36-52.

Al Yahya, K. (2011, April 14). Focus: Democracy in the Arab world. Gulf News. Retrieved March 8, 2012, from http://gulfnews.com/opinions/speakyourmind/ focus-democracy-in-arab-world-1.792545

Atherton, J. S. (2011). Doceo: Introduction to threshold concepts. Retrieved September 27, 2011, from http://www.doceo.co.uk/tools/threshold 3.htm

Badley, G. (2009). Academic writing as shaping and re-shaping. Teaching in Higher Education, 14(2), 209-219.

Bolitho, R. (2012, March 8-10). The fifth skill. $18^{\text {th }}$ International TESOL Arabia Conference: Achieving Excellence Through Life Skills Education. Dubai Women's College. Dubai, the United Arab Emirates.

Carey, S. (1991). Knowledge acquisition: Enrichment or conceptual change? In S. Carey \& R. Gelman (Eds.). The epigenesis of the mind: Essays biology and cognition. New Jersey: Erlbaum.

Carey, S. (2000). Science education as conceptual change. Journal of Applied Developmental Psychology, 21(1), 13-19.

Carey, S. (2004). Bootstrapping and the origin of concepts. Daedalus, 133(1) (Winter), 59-68.

Chanock, K. (2002, November 29-30). From mystery to mastery. Proceedings of the Language and Academic Skills Conference (CD-Rom). University of Wollongong, Australia.

Cottrell, S. (2001). Teaching study skills and supporting learning. Hampshire: Palgrave Macmillan.

Cottrell, S. (2005). Critical thinking skills. Hampshire: Palgrave Macmillan.

Cousin, G. (2006). Threshold concepts, troublesome knowledge and emotional capital. In J. H. F. Meyer \& R. Land (Eds.), Overcoming barriers to student understanding: Threshold concepts and troublesome knowledge (pp. 134-147). London: Routledge.

Daniel, J. (2003, January 23-25). Education for all in the Arab world: Past, present and future.

Meeting of Arab Education Ministers on Education for All, Beirut. Retreived March 5, 2012, from http://portal.unesco.org/education/en/ev.phpURL ID=28052\&URL DO=DO TOPIC\&URL SECTION=201.htm|

Davies, M. (2011). Study skills for international postgraduate students. Basingstoke: Palgrave Macmillan.

Derrida, J. (1994). Roundtable discussion with Jacques Derrida. Retrieved November 12, 2011, from www.hydra.umn.edu/derrida/vill1.html.

Entwhistle, N., McCune, V., \& Hounsell, J. (2002, September). Approaches to studying and perceptions of university teaching-learning environments: Concepts, measures and preliminary findings. Occasional Report 1: Enhancing Teaching-Learning Environments in Undergraduate Courses Project. University of Edinburgh, Scotland.

Hancock, D. R., \& Algozzine, B. (2006). Doing case study research. New York: Teachers College Press.

Hart, C. (1998). Doing a literature review. London: Sage.

Harwood, N., \& Hadley, G. (2004). Demystifying institutional practices: Critical pragmatism and the teaching of academic writing. English for Specific Purposes, 23(4), 355-377.

Johns, A. M. (1997). Text, role and context: Developing academic literacies. Cambridge: CUP.

Johnson, A., \& Clerehan, R. (2005). A rheme of one's own: How 'original' do we expect students to be? Journal of University Teaching \& Learning Practice, 2 (3), 36-47. 
Khasawneh, F. M. S. (2010). Writing for academic purposes: Problems faced by Arab postgraduate students of the College of Business, ESP World, Issue 2 (28), Volume 9: 1-23. Retrieved May 5, 2-13, from http://www.esp-world.info

Lloyd, M., \& Bahr, N. (2010). Thinking critically about critical thinking in higher education. International Journal for the Scholarship of Teaching and Learning, $4(2), 1-16$.

Macdonald, R., \& Carroll, J. (2006). Plagiarism - a complex issue requiring a holistic institutional approach. Assessment \& Evaluation in Higher Education, 31(2), 233 -245 .

Magyar, A. (2012). Plagiarism and attribution: An academic literacies approach? Journal of Learning Development in Higher Education, 4, 1-20.

McGowan, U. (2005). Academic integrity: An awareness and development issue for students and staff. Journal of University Teaching and Learning Practice, 2(3), 48-57.

Memering, D., \& Palmer, W. (2002). Discovering arguments: An introduction to critical thinking and writing with readings. NJ: Prentice Hall.

Meyer, J. H. F., \& Land, R. (2003). Threshold concepts and troublesome knowledge: Linkages to ways of thinking and practising within the disciplines. Occasional Report 4: Enhancing Teaching-Learning Environments in Undergraduate Courses Project. United Kingdom: Leeds University.

Ozmen, K. S. (2008). Current state and understanding of critical thinking in higher education. Cilt, 28(2), 109-127.

Pecorari, D. (2003). Plagiarism and patchwriting in academic second language writing. Journal of Second Language Writing, 12, 317-345.

Pithers, R. T., \& Soden, R. (2000). Critical thinking in education. Educational Research, 42(3), 237-249.

Emirates Centre for Strategic Studies and Research (ECCSR). (2004). Improving teaching standards in the Arab world. Retrieved March 2, 2012, from http:// www.ecssr.ac.ae/ECSSR/print/ft.jsp?lang=en\&ftld=/FeatureTopic/ECSSR/ FeatureTopic 0486.xml

Umair, N. (2011). Problems of multi-ability academic English writing classes in Arab countries. Arab World English Journal, 2(2), 230-242.

Walker, J. (1998). Student plagiarism in universities. What are we doing about it? Higher Education Research and Development, 17(1), 89-106.

Whitaker, B. (2009). Educational reform in the Arab world: The stifling of ideas. Retrieved February 14, 2012, from http://www.al-bab.com/arab/background/ educational reform.htm

Wilson, N. S., \& Smetana, L. (2011). Questioning as thinking: A metacognitive framework to improve comprehension of expository text (pp. 84-90). Literacy UKLA. Oxford: Blackwell Publishing.

Xie, X. J. (2012). Cultivating college students' critical thinking ability through readingdiscussion-writing approach. Sino-English Teaching, 9(5), 1145-1149.

Yin, R. K. (2003) Case study research: Designs and methods (3rd ed.). Thousand Oaks, CA: Sage.

\section{About the author}

From 2010 to 2013, Radhika lyer-O'Sullivan was the Learning and Teaching Advisor at the British University in Dubai. She was responsible for the Academic Success Unit, which provides learner support through academic literacy classes and individual support via the Writing Centre. Prior to that, she was the ESL Teacher Educator at the same institution. Her professional experiences include teaching ESL, EFL, EAP, teacher training and mentoring at tertiary levels in both Malaysia and Dubai. Her current research interests are in teaching and learning in higher education, developing culture-inclusive EAP curriculum for postgraduate students, and teacher development through action research. 